\title{
PENGARUH PUBLIC SERVICE MOTIVATION DAN ORGANIZATIONAL CITIZENSHIP BEHAVIOR TERHADAP KINERJA ORGANISASI PEMERINTAHAN
}

\author{
Puput Tri Komalasari, Moh. Nasih, dan Teguh Prasetio* \\ Universitas Airlangga dan Universitas Gajayana
}

\begin{abstract}
Public sector organizations, namely governments, are described as "non-productive and inefficient organization". This negative image of public sector organizations has arisen as a consequence of low public sector organization performance. Public sector performance improvement can be done by manipulating motivational dimensions of public service employee. This research aims to empirically test effect of public service motivation and organizational citizenship behavior (OCB) on organizational performance in the public sector of Indonesia. In addition, this study also focuses on individual factor of motivation, such as job satisfaction and organizational commitment. This paper employed 108 respondens that were sampled using convenient sampling. The result showed that there were positive significant influences of public service motivation and job satisfaction on organizational performance. Unfortunately, this study failed to give a proof that OCB influences organizational performance. Moreover, this study showed that there is differences level of motivational between men and women. On average, women have job satisfaction and public service motivation higher than men. This imply that women more satisfy at work than men, and women more likely to value intrinsic reward than men.
\end{abstract}

Keywords: organizational performance, public service motivation, organizational citizenship behavior, job satisfaction, organizational commitment.

\section{Pendahuluan}

Good governance telah menjadi ideologi baru negara-negara dan lembagalembaga donor internasional dalam mendorong negara-negara anggotanya menghormati prinsip-prinsip ekonomi pasar dan demokrasi sebagai prasyarat dalam pergaulan internasional. Istilah good governance mulai mengemuka di Indonesia pada akhir tahun 1990 seiring dengan interaksi antara pemerintah Indonesia dengan negara-negara luar dan lembaga-lembaga donor. Dengung good governance semakin menggema ketika Indonesia terpuruk akibat dari krisis multidimensional pada tahun 1997.

Seiring dengan meningkatkan sorotan terhadap penerapan good governance, konsep New Public Management (NPM) mengemuka. Munculnya NPM ini 
utamanya ditujukan untuk mereformasi manajemen di sektor publik dari administrasi keuangan tradisional menjadi manajemen publik. Public services (dalam hal ini adalah pemerintah) selama ini dipandang sebagai bagian dari organisasi ekonomi yang "tidak produktif" serta tidak efisien. Citra negatif yang melekat pada organisasi pemerintahan tidak terlepas dari kinerja organisasi yang belum memuaskan stakeholder nya. New Public Management (NPM) hadir ditengah ketidakpercayaan masyarakat terhadap kinerja organisasi pemerintah terutama di negara-negara sedang berkembang.

NPM didesain untuk membenahi problem-problem pemerintah seperti buruknya citra birokrasi, desain program dan kegiatan yang lemah serta defisiensi kinerja. Buruknya citra dan kinerja pemerintah ini tidak terlepas dari peran serta individuindividu yang terlibat dalam pelayanan publik (aparat pemerintah). Guna meningkatkan kinerja organisasi pemerintahan, maka kinerja individual (yang diwakili dengan aparat pemerintah) juga harus ditingkatkan. Kim (2005) mengemukakan bahwa faktor individu merupakan prediktor yang penting bagi kinerja organisasi pemerintahan.

Rainey dan Steinbaver (1999) telah membangun suatu kerangka teori tentang sebuah organisasi pemerintahan yang efektif. Model yang diajukan oleh Rainey dan Steinbaver (1999) adalah bahwa sebuah organisasi pemerintahan yang efektif memiliki motivasi yang tinggi diantara anggota-anggotanya yang meliputi public service motivation, mission motivation dan task motivation. Model yang dirancang oleh Rainey dan Steinbaver (1999) ini tidak terlepas dari hasil penelitian Crewson (1997) yang menyatakan bahwa terdapat perbedaan motivasional antara karyawan/pegawai yang bekerja di sektor publik dan sektor privat. Hal ini mempertegas bahwa harus ada pembedaan terhadap upaya-upaya untuk meningkatkan motivasi kerja antara karyawan di sector public dan privat. Manajer organisasi sektor publik seyogyanya tidak mengadopsi secara langsung teori-teori motivasional yang mayoritas dibangun dengan latar belakang sektor privat.

Selain public service motivation, faktor lain yang turut mempengaruhi kinerja individual yang pada akhirnya membawa pada kinerja organisasional adalah organizational citizenship behavior (OCB). OCB adalah perilaku karyawan/pegawai yang melebihi tugas yang telah ditetapkan. Perilaku OCB ini diharapkan dapat meningkatkan kefektivan organisasi. Perilaku OCB di sektor publik diharapkan dapat meningkatkan kinerja organisasi sektor publik.

Beberapa penelitian telah dilakukan untuk menguji public service motivation. Namun, mayoritas penelitian tersebut berupaya untuk melihat perbedaan motivasi kerja antara sektor publik dan privat (Crewson, 1997 dan Houston, 2000) dan meneliti dimensi-dimensi dari public service motivation itu sendiri (Perry, 1996 dan Brewer, Shelden dan Facer II, 2000). Sedikit sekali penelitian yang menguji keterkaitan antara public sector motivation dan kinerja organisasi pemerintahan. 
Penelitian tentang OCB juga telah banyak dilakukan dalam setting profit organization. Sementara itu, public service sebagai lembaga yang dituntut untuk bisa memberikan excellent services dituntut untuk bisa lebih meningkatkan kinerjanya. Jadi, penelitian ini ingin mencoba menjawab permasalahan utama yaitu:

1. Apakah terdapat public service motivation dalam organisasi pemerintahan?

2. Apakah fenomena OCB benar-benar terjadi dalam organisasi pemerintahan?

3. Bagaimanakah pengaruh public service motivation dan OCB terhadap kinerja organisasi pemerintahan?

Selain public service motivation dan $O C B$, beberapa penelitian juga mendokumentasikan adanya pengaruh kepuasan kerja dan komitmen organisasional terhadap kinerja organisasional (Liou dan Nyhan, 1994 dan Norris dan Neibuhr, 1984)

\section{Landasan Teori dan Pengembangan Hipotesis}

\section{Kinerja Organisasional}

Kinerja organisasi merupakan suatu konstruk yang penting dalam penelitian manajemen yang menunjukkan ukuran keberhasilan sebuah organisasi atau perusahaan. Sedemikian pentingnya sebuah kinerja dapat diekspresikan dalam jargon "If you can't define performance, you can't measure or manage it". Ditinjau dari sisi akademisi, kinerja organisasi juga merupakan suatu variabel dependen yang dikaitkan dengan ukuran-ukuran akuntansi, kepuasan pelanggan, produktivitas, dan juga kepuasan karyawan. Namun demikian, pengukuran dan pendefinisian kinerja organisasional di sektor publik bukanlah hal yang mudah. Kesulitan dalam pengukuran kinerja organisasi publik lebih disebabkan karena konstituen dari organisasi sektor publik yang bermacam-macam, dan masing-masing konstituen memiliki serta menuntut penekanan atau prioritas kinerja yang berbeda-beda.

Upaya untuk mengoperasionalisasi kinerja organisasional perlu dibedakan antara kinerja organisasi sektor publik dan privat. Roger (1994) sebagaimana dikutip oleh Mwita (2000) mendefinisikan kinerja sebagai hasil (outcome) dari sebuah pekerjaan karena mereka memberikan dukungan/kontribusi yang kuat/besar terhadap tujuan strategis organisasi, kepuasan pelanggan dan kontribusi ekonomis. Campbell (1990) sebagaimana dikutip oleh Mwita (2000) mengajukan premis bahwa kinerja (performance) adalah perilaku yang seharusnya dibedakan dari outcome untuk menghindari kontaminasi oleh faktor sistem yang secara nyata tidak dapat dikendalikan oleh performer. Kedua definisi tersebut mengindikasikan perlunya menentukan tujuan dari pengukuran kinerja, apakah mengukur outcome atau mengukur perilaku. Oleh sebab itu, menjadi penting bagi organisasi untuk membedakan outcome, perilaku dan alat pengukuran kinerja. 
Popovich (1998) dalam Kim (2005) mendefinisikan high-performance organization sebagai kelompok karyawan yang menghasilkan barang dan jasa yang dibutuhkan pada tingkat kualitas yang lebih tinggi dengan sumber daya yang sama atau lebih sedikit. Brewer dan Selden (2000) menyatakan bahwa kinerja organisasional sektor publik lebih didasarkan pada persepsi dari anggota-anggota organisasi. Hal ini disebabkan karena sulitnya memperoleh data historis yang obyektif yang digunakan sebagai dasar evaluasi kinerja. Ketika data obyektif tidak tersedia, maka pengukuran kinerja organisasional dapat menggunakan metode alternatif, yaitu pengukuran kinerja organisasional yang subyektif atau perseptif (Allen dan Helms, 2002). Meskipun validitas dari ukuran kinerja perseptif ini diragukan, namun beberapa penelitian telah mendokumentasikan adanya korelasi positif antara ukuran perseptif dan obyektif (misalnya Dollinger dan Golden, 1992). Kim (2005) membedakan kinerja organisasi sektor publik ke dalam 2 dimensi, yaitu dimensi internal dan dimensi eksternal. Masing-masing dimensi tersebut dispesifikasikan mengikuti nilai-nilai yang terkait dengan kinerja, yaitu efisiensi, keefektivan dan kewajaran. Terdapat beberapa faktor yang mempengaruhi kinerja organisasional, diantaranya adalah faktor personal (seperti motivasi dan komitmen), leadership (kepemimpinan), kualitas dan dukungan yang diberikan oleh kelompok (rekan kerja), sistem kerja dan fasilitas dan faktor-faktor kontekstual (situasional). Penelitian ini mengambil faktor personal dalam menguji kinerja organisasional.

\section{Public Service Motivation}

Public service motivation (selanjutnya disingkat PSM) dapat didefinisikan sebagai general altruistic motivation untuk melayani kepentingan suatu komunitas, negara atau masyarakat. Perry dan Wise (1990) telah mengajukan teori public service motivation. Keduanya mendefinisikan PSM sebagai kecenderungan individual untuk merespon terhadap motif-motif dasar yang unik dalam institusi dan organisasi publik. Teori ini didasarkan pada pendapat bahwa terdapat orang-orang yang tertarik dan termotivasi untuk bekerja di sektor publik. Tiga motif yang dicirikan dalam PSM, yaitu motif rasional, norma dan afektif. Motif rasional didasarkan pada individual utility maximization, yaitu bahwa individu tertarik untuk bekerja di sektor publik karena memiliki kepentingan untuk mendukung sektor privat tertentu ketika ia memiliki kewenangan atau andil dalam perumusan kebijakan publik. Motif normatif didasarkan ada suatu keinginan untuk melayani kepentingan publik, loyalitas terhadap tugas dan pemerintah, sedangkan motif afektif didasarkan pada faktor emosional, yaitu komitmen terhadap sebuah program yang didasarkan atas suatu keyakinan mengenai manfaat sosialnya dan rasa patriotisme.

Secara spesifik, Perry dan Wise (1990) menghipotesiskan bahwa:

1. Semakin tinggi PSM yang dimiliki individu, maka semakin besar kemungkinannya bahwa ia akan menjadi keanggotaan di organisasi sektor publik. 
2. PSM berhubungan secara positif dengan kinerja individual di organisasi sektor publik.

3. Organisasi sektor publik yang memiliki anggota dengan PSM yang tinggi akan mengurangi ketergantungannya terhadap penggunaan insentif yang berguna untuk mengelola kinerja organisasional secara efektif.

Lebih lanjut, Perry dan Wise (1990) menunjukkan bahwa jika dibandingkan dengan karyawan di sektor privat, karyawan yang bekerja di sektor publik lebih menitik beratkan pada nilai-nilai penghargaan (reward) intrinsik dan manfaat pekerjaan ketika melayani masyarakat dan kepentingan publik.

Beberapa riset empiris telah menunjukkan bahwa terdapat perbedaan motivasional antara karyawan di sektor privat dan publik. Crewson (1997) menunjukkan bahwa rasa ingin membantu orang lain dan menjadi orang yang memberikan manfaat bagi publik lebih dimiliki oleh karyawan sektor publik dibandingkan sektor privat. Sedangkan karyawan sektor privat lebih menilai pada aspek promosi dan keamanan/kelangsungan pekerjaan. Lewis dan Alonso (1999) menemukan hubungan yang positif antara PSM dan kinerja organisasi.

\section{Organizational Citizenship Behavior}

Dennis Organ (1988) sebagaimana dikutip oleh Paine dan Organ (2000) mendefinisikan OCB sebagai perilaku individual yang bersifat discretionary, yang secara tidak langsung atau eksplisit diakui oleh system reward yang formal, dan secara keseluruhan mendorong berjalannya organisasi secara efektif. Dasar pemikiran munculnya OCB tidak terlepas dari fenomena yang disebut sebagai "warga negara yang baik (good citizen)". Seorang warga negara yang baik adalah seseorang yang membantu tetangganya, memilih, berpartisipasi dalam aktivitas kemasyarakatan dll. Dengan kata lain, seseorang yang melakukan tindakan yang tidak diwajibkan namun memberikan kontribusi terhadap kesejahteraan komunitas.

Dengan menggunakan kerangka berpikir yang sama, good organizational citizens dapat didefinisikan sebagai karyawan/pegawai yang memberikan kontribusi terhadap berfungsinya organisasi secara efektif yang tidak secara eksplisit diminta (discretionary) dan tidak ada reward secara formal (insentif). Secara sederhana, OCB dapat berbentuk:

1. Pegawai yang membantu memecahkan permasalahan orang lain yang diluar kewenangan dan tanggungjawab pekerjaannya.

2. Pegawai yang secara aktif berpartisipasi dalam pertemuan tim ketika membicarakan perbaikan dan pembenahan pekerjaan.

3. Pegawai senior (telah berpengalaman) yang memberikan pelatihan kepada pegawai baru diluar jam kerjanya. 
Perilaku-perilaku tersebut secara normatif dapat berkontribusi pada peningkatan kinerja baik secara teamwork maupun organisasional.

Beberapa penelitian telah menunjukkan adanya korelasi positif antara OCB dan kinerja teamwork. Nielsen dan Sundstrom (2003) telah melakukan studi lapangan untuk menguji pengaruh dari OCB dan task interdependence terhadap kinerja teamwork. Hasilnya menunjukkan bahwa OCB berkorelasi secara positif terhadap kinerja teamwork.

\section{Komitmen Organisasi}

Konsep komitmen dalam organisasi telah banyak dibahas pada diskusi dan penelitian terkait dengan faktor-faktor yang mendorong munculnya komitmen organisasi serta aspek yang terpengaruh oleh munculnya komitmen organisasi. Porter et. al (1974) sebagaimana dikutip oleh Foote et. al (2005) memberikan konsep komitmen organisasi sebagai berikut:

1. Keyakinan dan keberterimaan terhadap tujuan dan sasaran organisasi.

2. Keinginan (willingness) untuk bekerja keras atas nama organisasi.

3. Upaya untuk tetap berada dalam organisasi.

Secara umum, komitmen organisasi dapat dipahami sebagai keterikatan karyawan secara psikologis terhadap organisasi. Terdapat beberapa definisi dan pengukuran komitmen organisasi yang telah dikembangkan oleh beberapa peneliti. Meyer dan Allen (1991) mencoba untuk mengintegrasikan berbagai definisi komitmen tersebut dengan membuat model komitmen yang terdiri 3 komponen, yaitu:

1. Affective commitment (komitmen afektif), yaitu keterikatan karyawan secara psikologis kepada organisasi yang bersifat positif. Artinya bahwa karyawan tersebut mengafiliasikan dirinnya dengan tujuan organisasi dan tetap ingin menjadi bagian dari organisasi tersebut.

2. Continuance commitment, yaitu suatu komitmen yang 'mengharuskan' seseorang untuk tetap menjadi anggota organisasi dengan alasan bahwa biaya yang harus ditanggung (baik economic cost maupun social cost) lebih tinggi jika ia keluar dari organisasi (side bet theory).

3. Normative commitment, komitmen individual untuk tetap menjadi anggota organisasi lebih karena adanya suatu kewajiban moral. Sebagai contoh ketika sebuah organisasi telah memberikan pelatihan ataupun investasi dalam pengembangan sumberdaya manusia (anggotanya), maka anggota organisasi tersebut cenderung merasa memiliki kewajiban 'moral' untuk tetap menjadi anggota organisasi dalam rangka 'membayar hutang'. Jadi, anggota organisasi berkomitmen terhadap organisasi karena merasa 'seharusnya' memiliki komitmen tersebut. 
Ketiga komponen komitmen tersebut tidak bersifat mutually exclusive, artinya bahwa seseorang bisa memiliki affective commitment, continuance commitment maupun normative commitment secara simultan atau dalam waktu yang bersamaan dengan tingkat intesitas yang berbeda-beda.

Komitmen organisasi tidak hanya menggambarkan loyalitas pasif yang dimiliki oleh anggota organisasi melainkan juga tindakan aktif anggota organisasi untuk memberikan yang terbaik bagi organisasi sehingga tujuan organisasi dapat tercapai dan keberlangsungan organisasi tetap dapat dipertahankan. Jadi, keberadaan komitmen organisasi ini diharapkan dapat meningkatkan kinerja organisasional.

Jika dikaitkan dengan kinerja organisasional, secara normatif, munculnya komitmen organisasi yang tinggi akan menimbulkan tingkat retensi yang tinggi sehingga kinerja organisasional diharapkan meningkat. Dari ketiga komponen yang dikemukakan oleh Meyer dan Allen (1991) tersebut, affective commitment dipandang lebih penting bagi peningkatan kinerja organisasional dibandingkan dengan continuance atau normative commitment. Somers dan Birnbaum (2000) menemukan bahwa affective commitment berkorelasi positif dengan kinerja (outcomes), sedangkan continuance commitment berkorelasi negatif dengan kinerja. Dukungan empiris terhadap pentingnya affective commitment di organisasi publik juga dikemukakan oleh Liou dan Nyhan (1994) yang menyatakan bahwa komitmen karyawan publik (pegawai negeri sipil) lebih didasarkan pada keterikatan mereka secara psikologis terhadap organisasi publik dan menjadi terlibat didalamnya.

\section{Kepuasan Kerja}

Kepuasan kerja (job satisfaction) didefinisikan sebagai kondisi emosional yang positif dan menyenangkan yang berasal dari penilaian atas pekerjaan seseorang atau pengalaman kerja. Kepuasan kerja merupakan respon afektif atau emosional terhadap berbagai aspek pekerjaan. Variabel kepuasan kerja ini juga dianggap penting mengingat keberadaannya sangat terkait erat dengan variabel-variabel kerja yang lain, seperti motivasi, keterlibatan dalam pekerjaan, OCB, komitmen organisasional, dan job performance.

Petty, McGee dan Cavender (1984) mengidentifikasikan ada 3 model hubungan kepuasan kerja dan kinerja organisasional, yaitu:

1. Kepuasan mendorong kinerja

2. Kinerja mendorong munculnya kepuasan

3. Hubungan antara kepuasan dan kinerja dimoderasi oleh variabel lain

Model hubungan yang pertama, yaitu kepuasan mendorong peningkatan kinerja dilandasi oleh studi Hawthorne pada akhir 1920 an dan awal 1930 an. Hasil studi 
tersebut mengindikasikan bahwa peningkatan kepuasan kerja berpengaruh positif terhadap kinerja organisasional. Namun demikian, riset empiris yang telah banyak dilakukan menunjukkan hasil yang tidak konsisten. Banyak penelitian empiris yang tidak berhasil menemukan hubungan/keterkaitan antara kepuasan kerja dengan kinerja organisasional. Kegagalan dalam menemukan hasil yang konsisten bisa jadi disebabkan oleh faktor agregasi dalam mengoperasionalisasi hubungan antara kepuasan kerja dengan kinerja organisasional (Fisher, 1980).

Norris dan Neibuhr (1984) mencoba meneliti hubungan antara kepuasan kerja dengan kinerja organisasional dengan memasukkan dimensi personality sebagai variabel kontrol. Hasilnya menunjukkan bahwa hubungan antara kepuasan kerja dengan kinerja organisasional semakin kuat ketika karyawan memiliki dimensi locus of control internal.

Hipotesis penelitian yang dirumuskan berdasarkan kerangka teori tersebut diatas adalah PSM, OCB, komitmen organisasional dan kepuasan kerja berpengaruh positif terhadap kinerja organisasional.

\section{Metode Penelitian}

Penelitian ini menggunakan sampel pegawai pemerintah daerah yang bekerja di kabupaten atau kotamadya di lingkup propinsi Jawa Timur. Metode pengambilan sampel menggunakan convenient sampling. Sebanyak 145 kuesioner dibagikan kepada pegawai pemerintah daerah yang bekerja di bagian/fungsi keuangan di masing-masing unit kerja. Kuesioner disebarkan di 5 pemerintah daerah, yaitu kabupaten Bangkalan sebanyak 33 kuesioner, kabupaten Pacitan sebanyak 35, kabupaten Probolinggo sebanyak 32 kuesioner, kabupaten Kediri sebanyak 34 kuesioner, dan pemerintah propinsi Jawa Timur sebanyak 11 kuesioner. Total sampel yang dapat diproses dalam penelitian ini adalah 108 kuesioner. Sebanyak 37 kuesioner tidak dapat digunakan sebagai sumber data karena ada item-item pertanyaan yang tidak diisi atau tidak sah.

Instrumen yang digunakan dalam penelitian ini mengadopsi instrument yang telah digunakan oleh Kim (2005). Variabel dependen yang digunakan adalah kinerja organisasional dengan 12 item pertanyaan. Sedangkan variabel independen terdiri dari kepuasan kerja dengan 8 item pertanyaan, komitmen afektif dengan 3 item pertanyaan, public sector motivation dengan 5 item pertanyaan, dan OCB dengan 9 pertanyaan. Masing-masing pertanyaan dijawab dengan menggunakan 5 skala likert dengan alternatif jawaban dari "sangat tidak setuju" sampai ke "sangat setuju".

Berikut ini disajikan data latar belakang responden dengan melihat variabelvariabel demografis. 
Tabel 1

Deskripsi Responden

\begin{tabular}{llc}
\hline \multicolumn{1}{c}{ Variabel Demografis } & \multicolumn{1}{c}{ Karakteristik } & Jumlah (\%) \\
\hline Jenis kelamin & Laki-Laki & 67 \\
& Perempuan & 33 \\
\hline Usia & 20 an & 5,8 \\
& 30 an & 31,8 \\
& 40 an & 48,5 \\
50 an keatas & 13,9 \\
\hline Masa Kerja & 0-10 tahun & 17,6 \\
& 10-20 tahun & 36,1 \\
& 20 tahun keatas & 45,4 \\
\hline
\end{tabular}

Sumber: Data yang diolah

Berdasarkan tabel 1, terlihat bahwa mayoritas responden adalah laki-laki dengan masa kerja di pemerintah daerah mayoritas selama 10 sampai lebih dari 20 tahun. Rata-rata umur responden berada dalam kisaran 30 sampai 50 tahun.

\section{Hasil dan Pembahasan}

Berdasarkan hasil analisis korelasi pada tabel 2 terlihat bahwa variabel kepuasan kerja, komitmen organisasional, public service motivation dan OCB berhubungan positif dengan kinerja organisasional dengan koefisien korelasi masing-masing 0,752 $(p<0,01), 0,541 \quad(p<0,01), 0,371 \quad(p<0,01)$ dan 0,317 $(p<0,01)$. Disamping itu terlihat bahwa terdapat korelasi positif yang signifikan diantara variabel independen yang digunakan dalam penelitian ini. Tabel 2 menunjukkan bahwa variabel kepuasan kerja memiliki korelasi terbesar dengan kinerja organisasional. Selain itu, kepuasan kerja juga memiliki korelasi yang tinggi dengan komitmen organisasional. Signifikansi dari seluruh korelasi diantara variabel dependen dan independen menunjukkan bahwa masing-masing variabel saling berkorelasi.

Tabel 2

Hasil Analisis Korelasi dan Deskriptif

\begin{tabular}{|c|c|c|c|c|c|c|c|}
\hline Variabel & PSM & OCB & $\begin{array}{c}\text { Kepuasan } \\
\text { Kerja }\end{array}$ & $\begin{array}{c}\text { Komitmen } \\
\text { Organisasional }\end{array}$ & $\begin{array}{l}\text { Rata- } \\
\text { Rata }\end{array}$ & $\begin{array}{l}\text { Deviasi } \\
\text { Standar }\end{array}$ & $\begin{array}{c}\text { Jumlah } \\
\text { Observasi }\end{array}$ \\
\hline $\begin{array}{l}\text { Kinerja } \\
\text { Organisasional }\end{array}$ & 0,371 & 0,317 & 0,752 & 0,541 & 3,84 & 0,444 & \\
\hline PSM & & 0,346 & 0,300 & 0,436 & 3,97 & 0,544 & \\
\hline $\mathrm{OCB}$ & & & 0,362 & 0,337 & 3,48 & 0,463 & 108 \\
\hline Kepuasan Kerja & & & & 0,607 & 3,75 & 0,467 & \\
\hline $\begin{array}{l}\text { Komitmen } \\
\text { Organisasional }\end{array}$ & & & & & 4,19 & 0,614 & \\
\hline
\end{tabular}

Sumber: Data yang diolah

Data deskriptif atas variabel-variabel yang digunakan dalam penelitian ini ditunjukkan juga di tabel 2. Hasil analisis deskriptif menunjukkan bahwa nilai rata-rata dan deviasi standar tertinggi adalah pada variabel komitmen organiasional, artinya 
bahwa variasi data komitmen organisasional lebih tinggi dibandingkan variabel yang lain. Berikut ini disajikan hasil analisis deskriptif dikaitkan dengan aspek demografi gender:

Tabel 3

Analisis Deskriptif Berdasarkan Gender

\begin{tabular}{lcccc}
\hline \multirow{2}{*}{ Variabel } & \multicolumn{2}{c}{ Rata-Rata } & \multicolumn{2}{c}{ Deviasi Standar } \\
\cline { 2 - 5 } & Laki-Laki & Perempuan & Laki-Laki & Perempuan \\
\hline Kinerja & 3,796 & 3,928 & 0,459 & 0,407 \\
Organisasional & 3,928 & 4,067 & 0,488 & 0,641 \\
PSM & 3,457 & 3,459 & 0,418 & 0,548 \\
OCB & 3,696 & 3,856 & 0,469 & 0,449 \\
Kepuasan Kerja & 4,116 & 4,333 & 0,636 & 0,547 \\
Komitmen & 72 & 36 & 72 & 36 \\
Organisasional & \multicolumn{5}{c}{}
\end{tabular}

Tabel 3 menunjukkan bahwa secara rata-rata, perempuan memiliki variabel personal yang berbeda dengan laki-laki. Secara rata-rata, perempuan memiliki tingkat komitmen organisasional dan PSM yang lebih tinggi dibandingkan laki-laki. Hal yang sama berlaku untuk variabel kepuasan kerja. Secara deskriptif dapat disimpulkan bahwa perempuan memiliki komitmen organisasional yang lebih tinggi dibandingkan laki-laki. Namun, secara rata-rata baik laki-laki maupun perempuan memiliki tingkat OCB yang hampir sama. Artinya bahwa motivasi individual dalam rangka memberikan yang terbaik kepada organisasi tidak berbeda antara laki-laki dan perempuan.

Hasil analisis regresi untuk menguji pengaruh variabel independen terhadap variabel dependen dapat dilihat pada tabel 4 di bawah ini:

Tabel 4

Hasil Analisis Regresi Linier Berganda

\begin{tabular}{|c|c|c|c|}
\hline Variabel & Koefisien & $p$-value & Keterangan \\
\hline Konstanta & 0,780 & 0.08 & \\
\hline Kepuasan Kerja & 0,631 & 0,000 & Signifikan pada tingkat a 5\% \\
\hline Komitmen & 0,056 & 0,362 & Tidak signifikan secara statistik \\
\hline PSM & 0,112 & 0,059 & Signifikan pada tingkat a $10 \%$ \\
\hline$O C B$ & 0,004 & 0,955 & Tidak signifikan secara statistik \\
\hline$R^{2}$ & 0,592 & & \\
\hline Signifikansi F & 0,000 & & \\
\hline
\end{tabular}

Variabel dependen: Kinerja Organisasi

Sumber: Data yang diolah

Berdasarkan tabel 4 dapat dianalisis bahwa variabel yang berpengaruh terhadap kinerja organisasional adalah variabel kepuasan kerja dan public sector motivation. 
Variabel kepuasan kerja berpengaruh positif dan signifikan secara statistik terhadap kinerja organisasi. Variabel kepuasan kerja memiliki pengaruh yang dominan di bandingkan dengan variabel yang lain. Hal ini menunjukkan bahwa semakin tinggi kepuasan kerja yang dirasakan oleh responden maka kinerja organisasional juga semakin meningkat.

Variabel public service motivation juga berpengaruh positif dan signifikan terhadap kinerja organisasional. Namun kontribusi pengaruh variabel PSM jauh lebih kecil $(0,11,2)$ jika dibandingkan dengan kepuasan kerja $(0,631)$. Hal ini mengindikasikan bahwa dalam organisasi pemerintahan terdapat motivasi untuk melayani publik. Motivasi itu mendorong mereka untuk memilih sektor publik sebagai tempat untuk mencurahkan effort dan tenaganya. Hal ini konsisten dengan penelitian Alonso dan Lewis (2001) yang menemukan pengaruh positif antara PSM dengan kinerja pekerjaan.

Sementara itu, variabel komitmen dan OCB tidak berpengaruh secara signifikan terhadap kinerja organisasional dengan nilai signifikasi lebih dari $5 \%$. Hal ini menunjukkan bahwa komitmen organisasional dan OCB tidak memiliki pengaruh yang dominan dan signifikan dalam menentukan kinerja organisasi. Kondisi ini bisa dipahami karena jumlah pegawai pemerintah daerah yang cukup besar serta ada pembagian tugas yang jelas diantara mereka, sehingga masing-masing pegawai hanya akan melakukan pekerjaan yang berada dalam tugas pokok dan fungsinya. Kondisi ini menimbulkan rendahnya tingkat $O C B$ yang dimiliki oleh pegawai pemerintah daerah.

Analisis lebih lanjut dilakukan untuk melihat pengaruh variabel-variabel motivasional terhadap kinerja organisasional dengan mengontrol variabel gender. Hasil secara statistik ditunjukkan di tabel 5 dibawah ini:

Tabel 5

Hasil Analisis Regresi Berganda Berdasarkan Aspek Gender

\begin{tabular}{lcccc}
\hline \multirow{2}{*}{ Variabel } & \multicolumn{2}{c}{ Laki-Laki } & \multicolumn{2}{c}{ Perempuan } \\
\cline { 2 - 5 } & Koefisien & p-value & Koefisien & p-value \\
\hline Konstanta & 0,582 & 0.128 & 1,228 & 0,012 \\
Kepuasan Kerja & 0,667 & 0,000 & 0,670 & 0,000 \\
Komitmen & 0,079 & 0,276 & $-0,101$ & 0,414 \\
PSM & 0,000 & 0,997 & 0,277 & 0,003 \\
OCB & 0,122 & 0,187 & $-0,166$ & 0,119 \\
R2 & 0,631 & & 0,598 & \\
Signifikansi F & 0,000 & & 0,000 & \\
\hline
\end{tabular}

Variabel depeden: kinerja organisasional

Sumber: data yang diolah

Tabel 5 memberikan hasil yang konsisten dengan tabel 4 ketika tidak terdapat manipulasi aspek gender dalam pengujian hipotesis. Artinya bahwa hanya 2 
variabel yang memiliki pengaruh signifikan secara statistik terhadap kinerja organisasional, yaitu variabel kepuasan kerja dan PSM. Jika dilihat dari perbandingan di tabel 5, menunjukkan bahwa variabel kepuasan kerja dan PSM yang dimiliki oleh perempuan memberikan kontribusi yang lebih besar terhadap kinerja organisasional dibandingkan laki-laki.

Kondisi tersebut bisa dipahami berdasarkan kerangka berpikir bahwa perempuan dan laki-laki memiliki perbedaan dalam mengkomunikasikan sesuatu. Demikian pula dengan cara pandang terhadap sebuah reward yang diberikan oleh organisasi. Perempuan cenderung memberikan penilaian lebih pada kebutuhan sosial (social need), seperti bekerja bersama-sama dan saling membantu diantara anggota kelompok kerja. Berbeda dengan laki-laki yang lebih menyukai sistem kompensasi sebagai tolok ukur kepuasan dalam bekerja. Tang dan Talpade (1999) menemukan bahwa laki-laki cenderung menunjukkan kepuasan kerja yang tinggi ketika reward mereka dikaitkan dengan insentif moneter, sedangkan perempuan lebih merasakan kepuasan dalam bekerja ketika dikaitkan dengan teman kerja (co-worker).

\section{Simpulan}

Upaya untuk meningkatkan kinerja organisasional bisa diawali dengan meningkatkan kinerja individual. Kinerja individual dipengaruhi oleh banyak aspek termasuk didalamnya aspek motivasional secara personal. Aspek motivasional yang diuji dalam penelitian ini adalah public service motivation, organizational citizenship behavior, kepuasan kerja dan komitmen organisasional. Hasil penelitian ini menunjukkan bahwa dalam organisasi pemerintahan telah muncul motivasi pelayanan public dan organizational citizenship behavior (OCB). Kedua aspek tersebut dapat digunakan sebagai salah satu sarana untuk meningkatkan kinerja organisasional. Namun demikian, tingkat OCB yang ada di organisasi pemerintahan tidak terlalu besar jika dibandingkan dengan motivasi pelayanan publik. Hasil lebih lanjut menunjukkan bahwa kepuasan kerja dan public service motivation berpengaruh positif secara signifikan terhadap kinerja organisasional, sedangkan OCB tidak berpengaruh secara signifikan terhadap kinerja organisasional. Dikaitkan dengan aspek gender, terdapat perbedaan pengaruh aspek motivasional terhadap kinerja organisasional. Kepuasan kerja dan public service motivation pada perempuan mampu memberikan kontribusi yang lebih besar terhadap kinerja organisasional dibandingkan laki-laki.

Tindak lanjut atas hasil penelitian ini perlu dilakukan untuk melihat unit analisis dari OCB. Penelitian ini menggunakan individu sebagai unit analisis untuk melihat pengaruhnya terhadap kinerja organisasi. Penggunaan unit analisis kelompok kerja (group) OCB perlu dilakukan mengingat kinerja organisasi secara keseluruhan banyak didukung oleh kinerja teamwork. Kelemahan penelitian ini adalah tidak mempertimbangkan hubungan reciprocal antar variabel dependen dan independen. Disamping itu hasil penelitian ini juga dipengaruhi oleh variabel 
moderator yang tidak dimasukkan dalam analisis yang menurut beberapa penelitian mempengaruhi hubungan antara variabel dependen dan independen.

\section{Daftar Referensi}

Allen, R. S., dan M. M. Helms, 2002, Employee Perceptions of the Relationship Between Strategy, Rewards and Organizational Performance, Journal of Business Strategies, 19, 115-39.

Alonso, Pablo dan Gregory B. Lewis, 2001, Public Service Motivation and Job Performance: Evidence for Federal Sector, American Review of Public Administration, 31, 363-380.

Brewer, Gene A. dan Sally Coleman Selden, 2000, Work Motivation in the Senior Executive Service: Testing the High Performance Cycle Theory, Journal of Public Administration Research and Theory, 10, 531-550.

Brewer, Gene A., Sally Coleman Selden dan Rex L. Facer II., 2000, Individual Conception of Public Service Motivation, Public Administration Review, 60, 254-264.

Crewson, Philip E., 1997, Public-Service Motivation: Building Empirical Evidence of Incidence and Effect, Journal of Public Administration Research and Theory, 7, 499-518.

Dollinger, M. J., dan P. A. Golden, 1992, Interorganizational and Collective Strategies in Small Firms: Environmental Effects and Performance, Journal of Management, 18, 695-715.

Fisher, D. Cynthia., 1980, On the Dubious Wisdom of Expecting Job Satisfaction to Correlate with Performance, Academy of Management Review, 5, 607-612.

Foote, David A., Scott J. Seipel., Nancy B. Johnson., dan Michele K. Duffy., 2005, Employee Commitment and Organizational Policy, Management Decision, 43, 203-219.

Hourton, David J., 2000, Public-Service Motivation, Journal of Public Administration Research and Theory, 4, 713-727.

Kim, Sangmook., 2005, Individual-Level Factors and Organizational Performance in Government Organization, Journal of Public Administration Research and Theory, 15, 245-261.

Liou, K dan R. C., Nyhan, 1994, Dimensions of Organizational Commitment in the Public Sector: An Empirical Assessment, Public Administration Quarterly, 18, 99-118.

Meyer, J. P., dan Allen, N. J., 1991, A Three-Component Conceptualization of Organizational Commitment, Human Resource Management Review, 1, 6189.

Mwita, John Isaac., 2000, Performance Management Model, International Journal of Public Sector Management, 13, 19-37.

Nielsen m. Tjai., dan Eric Sundstrom, 2003, Organizational Citizenship Behavior and Work Team Performance: A Longitudinal Field Study, working paper, http://www.ssrn.com. 
Norris, Dwight R., dan Robert E. Neibuhr, 1984, Attributional Influences on the Job Performance-Job Satisfaction Relationship: Research Notes, Academy of Management Review, 27, 424-431.

Paine, Julie Beth., dan Dennis W. Organ., 2000, The Cultural Matrix of Organizational Citizenship Behavior: Some Preliminary Conceptual and Empirical Observation, Human Resource Management Review, 10, 45-59.

Perry, James L., 1996, Measuring Public Service Motivation: An Assessment of Construct Reliability and Validity, Journal of Public Administration Research and Theory, 6, 5-22.

Perry, James L., dan L. R. Wise, 1990, The Motivational Bases of Public Service, Public Administration Review, 50, 367-373.

Petty,M., Gail W McGee, dan Jerry W Cavender, 1984, A Meta-Analysis of the Relationships Between Individual Job Satisfaction and Individual Performance, Academy of Management Review, 9, 712-721.

Rainey, Hal. G dan Paula Steinbaver, 1999, Galloping Elephants: Developing Elements of a Theory of Effective Government Organizations, Journal of Public Administration Research and Theory, 9, 1-32.

Reichers., E. Arnon., 1985, A Review and Reconceptualization of Organizational Commitment, Academy of Management Review, 10, 465-476.

Somers, M., dan D. Birnbaum, 2000, Exploring the Relationship Between Commitment Profiles and Work Attitudes, Employee Withdrawal, and Job Performance, Public Personnel Management, 29, 353-365.

Tang, T. L. \& Talpade, M., 1999, Sex differences in satisfaction with pay and coworkers: Faculty and staff at a public institution of higher education. Public Personnel Management, 28, 345-349.

\footnotetext{
* Puput Tri Komalasari dan Moh. Nasih adalah dosen tetap Fakultas Ekonomi Universitas Airlangga (UNAIR). Kritik dan dan saran dapat langsung menghubungi penulis dengan alamat email puput tk@yahoo.com
} 